Annals of Warsaw University of Life Sciences - SGGW

Land Reclamation No 41, 2009: 19-39

(Ann. Warsaw Univ. of Life Sci. - SGGW, Land Reclam. 41, 2009)

\title{
Ozone concentration in ground-level air layer in north-western Poland - The role of meteorological elements
}

\author{
ROBERT KALBARCZYK, ELIZA KALBARCZYK \\ Department of Meteorology and Climatology \\ Agricultural University in Szczecin, Poland
}

\begin{abstract}
Ozone concentration in ground-level air layer in north-western Poland - The role of meteorological elements. The research aimed at recognising time structure and variability of tropospheric ozone as a function of daytime and nocturnal meteorological conditions, particularly in the spring season (March-May), as well as finding a weather cluster at which the highest $\mathrm{O}_{3}$ concentration occurs. Ozone concentrations recorded every hour during the two years and data on five other meteorological elements: total solar radiation, air temperature, relative air humidity, atmospheric pressure, wind direction and speed provided the input data for the analysis. The data were collected at Widuchowa weather station, north-western Poland, near the Polish-German border. The highest ozone concentration was observed at daytime day, under conditions of eastern wind, low relative air humidity (about 35\%), high values of total solar radiation (about $\left.209 \mathrm{~W} \cdot \mathrm{m}^{-2}\right)$, air temperature $\left(17.0^{\circ} \mathrm{C}\right)$, atmospheric pressure $(1016 \mathrm{hPa})$ and high wind speed $\left(2.7 \mathrm{~m} \cdot \mathrm{s}^{-1}\right)$. It is concluded that the magnitude of tropospheric ozone concentration recorded at Widuchowa is influenced by gaseous pollutants originating not only from the territory of Poland but also from Germany.
\end{abstract}

Key words: tropospheric ozone, time distribution, air quality-monitoring network, wind direction, cluster analysis.

\section{INTRODUCTION}

Tropospheric ozone is considered to be one of the major air pollutants. Much research proved a hazardous impact of ground-level ozone on phytocoenosis and human health, particularly in children and elderly people (Bytnerowicz et al. 2003; Manning et al. 2002; Maňkovska et al. 1999, 2002). Ozone in the troposphere originates from natural sources, mainly from lower stratosphere ozone layer. Photochemical reactions with nitrogen oxides $\left(\mathrm{NO}_{\mathrm{x}}\right)$ of natural origin contributes to the ozone production, as well as reactions from natural non-metal hydrocarbons such as isoprene and terpene. Apart from that, small quantities are also formed from atmospheric discharges at storms, as well as from other anthropogenic sources, where it is the result of ozone producing chemical processes through nitrogen dioxide photolysis, at ambient presence of carbon oxide and hydrocarbons, and other substrates of usually anthropogenic character. Tropospheric ozone origin is closely related to meteorological conditions such as air temperature, insolation and radiation, relative air humidity, wind speed and direction (Davis et al. 1998; Ośródka and Święch-Skiba 1997; Treffeisen and Halder 2000; Walczewski 2005). The level of tropospheric ozone concentration varies over daytime and over years, and depends on latitude, site profile and prevailing meteorological conditions, as well as 
the distance to air pollutants source and the time of their propagation (Baur et al. 2004; Davis et al. 1998; Elminir, 2005; Lehman et al. 2004; Mazzeo et al. 2005). Higher ozone concentrations are typically observed in rural areas rather than in city centres, hence the subject research has to be conducted in such, preferably in the vicinity of big urban agglomerations (Godłowska 2004; Godłowska, Tomaszewska 2006). Higher ozone concentrations, above the estimated threshold, have been observed in north-western Poland, both within urban areas and in the background ones (Landsberg-Uczciwek et al. 2007).

The research was aimed at recognising the time structure and variability for tropospheric ozone, as observed in Widuchowa weather station (north-western Poland), in relation to daily and nocturnal meteorological conditions, particularly in a spring season. In addition, a weather cluster of the highest ozone concentration in spring season was determined.

\section{MATERIALS}

Tropospheric ozone concentrations $\left(\mathrm{O}_{3}\right.$, in $\left.\mu \mathrm{g} \cdot \mathrm{m}^{-3}\right)$ recorded every hour, and data on other five meteorological elements, namely total solar radiation $\left(\mathrm{RAD}\right.$, in $\mathrm{W} \cdot \mathrm{m}^{-2}$ ), average temperature (TP, in $\left.{ }^{\circ} \mathrm{C}\right)$, relative air humidity $(\mathrm{RH}$, in $\%)$, atmospheric pressure ( $\mathrm{PH}$, in $\mathrm{hPa})$, and direction $(\mathrm{N}, \mathrm{NE}, \mathrm{E}, \mathrm{SE}, \mathrm{S}, \mathrm{SW}$, $\mathrm{W}, \mathrm{NW}$ ) and speed (WS, in $\mathrm{m} \cdot \mathrm{s}^{-1}$ ) of wind provided the input data. Data were collected over the period between 1st November 2005 and 31st October 2007 at Widuchowa weather station $\left(14^{\circ} 23^{\prime} \mathrm{E}, 53^{\circ} 17^{\prime} \mathrm{N}, 2 \mathrm{~m}\right.$ above the sea level), which is a part of the Polish State Monitoring for Environment network, located at the Polish-German border in the north-western Poland. Continuous measurements of ozone concentration were performed at two meters above ground level with a MLU 400E analyser by Monitor Labs at Widuchowa station. Standard measurement was based on UV radiation absorbed as the result of the inner resonance of $\mathrm{O}_{3}$ molecules, whereas the other meteorological elements were performed according to standards set by World Meteorological Organization.

\section{METHODS}

The dependence between $\mathrm{O}_{3}$ concentration and wind directions was investigated by linear regression analysis, though analysis covered only spring season (from March till May), i.e. when the highest average $\mathrm{O}_{3}$ concentration over the whole calendar year was noted, separately for days (from sunrise to sunset) and nights (from sunset till sunrise). A determination coefficient $\left(100 \mathrm{R}^{2}\right.$, in \%) served as the parameter measuring the regression function fitting to the empiric data. Parameters for the regression function were determined with the least squares method. A hypothesis on regression function significance, i.e. multiple regression coefficient, was tested with F-Snedecora test, while the significance of regression coefficients with a t-Student test (Sobczyk 1998).

Values for the wind speed, as independent variables were parameterised with a distribution other than normal, thus this variable was normalised with 
a function: $f(W S)=\ln (W S)$, where WS stands for wind speed (in $\mathrm{m} \cdot \mathrm{s}^{-1}$ ). Independent variable WS conformity with the normal distribution was tested with a Chi-square method at the assumed significance level $\mathrm{P} \leq 0.05$.

To identify a weather cluster, which favours highest $\mathrm{O}_{3}$ concentration in a spring season, a general cluster analysis was applied. Prior to the analysis, five meteorologicalelements were normalised according to the following formula:

$Z_{j}=X_{j}-\operatorname{Min}\left(x_{j}\right) / \operatorname{Max}\left(x_{j}\right)-\operatorname{Min}\left(x_{j}\right)$

where: $\operatorname{Max}(x j)$ and $\operatorname{Min}(x j)$ stand for maximum and minimum value of $i$-element, respectively. Normalised as such, all values of the meteorological elements fell within the $(0,1)$ interval (Dobosz 2001).

All the observations of the meteorological elements under the analysis were formed as clusters by means of a non-hierarchical $k$-means method, with an Euclidean distance, i.e. the geometric distance in the multidimensional space (Hartigan 1975; Holden and Brereton 2004). Clustering with the $k$-means consists in moving observations from cluster to cluster to find a maximised variance between particular clusters, while keeping the minimum variance within the analysed cluster. To determine the number of clusters a $\mathrm{v}$ -fold cross-validation test was used. The significance of differences between the separated clusters was assessed with the variance analysis by the Fisher's test at the level $\mathrm{P} \leq 0.05$ was applied (Dobosz 2001).

\section{RESULTS AND DISCUSSION}

\section{Time structure and variability of $\mathrm{O}_{3}$ concentration}

Average annual ozone concentration in the ground level of air was recorded as 61.5 $\mu \mathrm{g} \cdot \mathrm{m}^{-3}$ and it varied from $44.3 \mu \cdot \mathrm{g} \mathrm{m}^{-3}$ in the winter season to $82.5 \mu \mathrm{g} \cdot \mathrm{m}^{-3}$ in the spring season (Fig. 1). Bogucka (2006) reported similar results for the quantity and time distribution for $\mathrm{O}_{3}$ concentration in other four weather stations, located in various regions of Poland, and also found the highest ozone concentration to occur usually in spring.

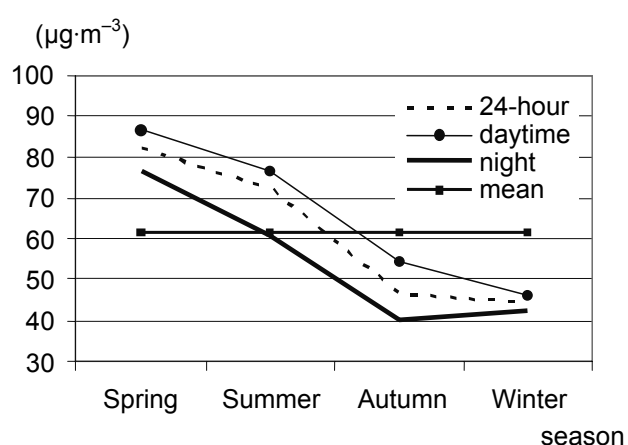

FIGURE 1. Average seasonal and annual ozone concentration in the ground-level air layer

Within the studied period ozone concentrations observed at daytime were usually higher than at night and reached 66.0 and $55.1 \mu \mathrm{g} \cdot \mathrm{m}^{-3}$, respectively. The minimum value at night is caused by ceased photochemical mechanism of converting primary NO to secondary $\mathrm{NO}_{2}$, and also by superiority of the oxidation fraction by ozone accumulated during the day (Felzer at al. 2007). The biggest differences between the ozone concentration values at daytime and at 
night were recorded in summer (16.1 $\mu \mathrm{g} \cdot \mathrm{m}^{-3}$ ), whereas the smallest in winter $\left(3.5 \mu \mathrm{g} \cdot \mathrm{m}^{-3}\right)$.

In the spring season, namely between 1st March and 31st May, the highest average $\mathrm{O}_{3}$ concentration, at both days and nights, were recorded in the period from 21st to 30th April when it reached 96.8 and $88.8 \mu \mathrm{g} \cdot \mathrm{m}^{-3}$, respectively, whereas the lowest ones in the period from 11th to 20th May, with values reaching 72.6 and $61.8 \mu \mathrm{g} \cdot \mathrm{m}^{-3}$, respectively (Fig. 2a). The biggest differences between daily and nocturnal ozone concentrations occurred in the period from 11th to 20th May $\left(10.8 \mu \mathrm{g} \cdot \mathrm{m}^{-3}\right)$, and in the period from 21st to $31 \mathrm{st}$ March $\left(10.5 \mu \mathrm{g} \cdot \mathrm{m}^{-3}\right)$, whereas the smaller ones in the period from 1st to 10th April $\left(6.2 \mu \mathrm{g} \cdot \mathrm{m}^{-3}\right)$. In the spring season the highest average ozone concentration at day were noted with the eastern $\left(98.8 \mu \mathrm{g} \cdot \mathrm{m}^{-3}\right)$, and northwest wind $\left(95.7 \mu \mathrm{g} \cdot \mathrm{m}^{-3}\right)$, which were respectively higher by 16.3 and 13.2 $\mu \mathrm{g} \cdot \mathrm{m}^{-3}$ than the average concentration for this season. The lowest values were recorded for south-eastern wind $\left(71.5 \mu \mathrm{g} \cdot \mathrm{m}^{-3}\right)$, whereas concentrations at night were the highest with north wind $\left(85.1 \mu \mathrm{g} \cdot \mathrm{m}^{-3}\right)$, and lowest ones with south wind $\left(66.3 \mu \mathrm{g} \cdot \mathrm{m}^{-3}\right)$ (Fig. 2b).

a)

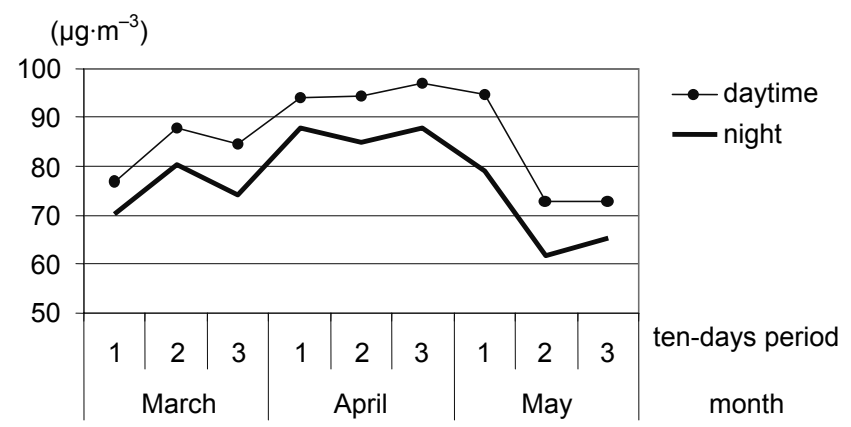

b)

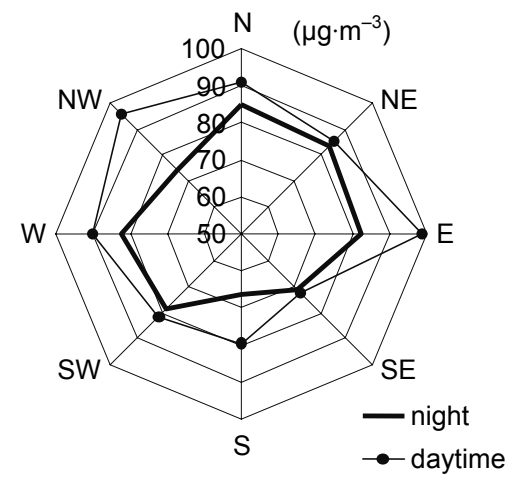

FIGURE 2. Average hourly ozone concentration in the ground-level air layer (a) and wind directions (b) 
The biggest differences in ozone concentrations between day and night with reference to the atmospheric circulation were recorded for northwestern $\left(21.3 \mu \mathrm{g} \cdot \mathrm{m}^{-3}\right)$ and eastern winds $\left(16.7 \mu \mathrm{g} \cdot \mathrm{m}^{-3}\right)$, while the smallest - for winds from south-east direction $(0.8 \mu \mathrm{g}$. $\cdot \mathrm{m}^{-3}$ ).

In the Figures 3, $4 \mathrm{a}$ and $4 \mathrm{~b}$ selected statistical characteristics of variability in $\mathrm{O}_{3}$ concentration in the periods of the spring season and the direction from which the air masses were moving are presented. Absolute maximum values of the hourly ozone concentrations were recorded always at daytime, regardless the atmospheric circulations (Fig. 3). The highest absolute, ozone concentration equal to $194.0 \mu \mathrm{g} \cdot \mathrm{m}^{-3}$, was observed in the spring season with the wind blowing from east, i.e. the same direction for which the highest average concentrations of $\mathrm{O}_{3}$ were noted. Variability of $\mathrm{O}_{3}$ concentration, as described by a standard deviation, was greater for the measurements performed at daytime than at night, and it varied from 24.2 to $39.9 \mu \mathrm{g} \cdot \mathrm{m}^{-3}$ for

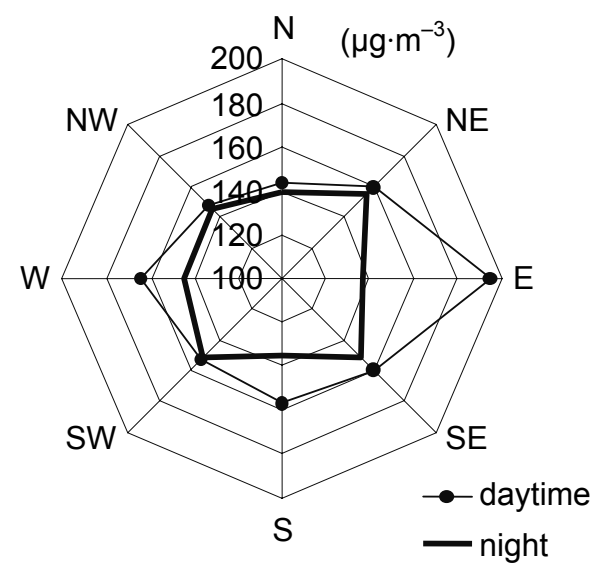

FIGURE 3. Absolute maximal ground-level ozone concentration values for wind directions measurements at day, and between 17.7 and $30.1 \mu \mathrm{g} \cdot \mathrm{m}^{-3}$ at night; in both cases the lowest variability was found for the period from 1st to 10th April, while the highest one for the period from 1st to 10th May (Fig. 4a). Standard deviations for hourly average $\mathrm{O}_{3}$ concentrations, when analysed with relation to the wind directions, were ranging at daytime: from $25.0 \mu \mathrm{g} \cdot \mathrm{m}^{-3}$ with south-western wind to $37.3 \mu \mathrm{g} \cdot \mathrm{m}^{-3}$ with eastern wind; at night it was considerably lower and ranged from $20.7 \mu \mathrm{g} \cdot \mathrm{m}^{-3}$ with southern wind to 30.3 $\mu \mathrm{g} \mathrm{m}^{-3}$ with eastern wind (Fig. $4 \mathrm{~b}$ ).

Ground-level concentration apart from a significant seasonal variability (Fig. 1), displays also daily variability, determined by latitude, site layout and meteorological conditions (particularly within mean latitudes) and the distance from the air pollutants emission source and their propagation time (Brace and Peterson 1998; Cooper and Peterson 2000; Treffeisen and Halder 2000). Figure 5 shows a distinct daily variability in the ozone concentration at Widuchowa station. The highest values for average concentrations, over $100 \mu \mathrm{g} \cdot \mathrm{m}^{-3}$, were recorded between $2 \mathrm{pm}$. and $6 \mathrm{pm}$., with a maximum at $4 \mathrm{pm}$. $\left(104.6 \mu \mathrm{g} \cdot \mathrm{m}^{-3}\right)$; the lowest values, below $66 \mu \mathrm{g} \cdot \mathrm{m}^{-3}$, between $5 \mathrm{am}$. and $8 \mathrm{am}$., and minimum at $6 \mathrm{am}$. $\left(64.6 \mu \mathrm{g} \cdot \mathrm{m}^{-3}\right)$. Similar daily distribution in ozone concentration was found in the Mount Rainier National Park Region (U.S.A.) by Brace and Peterson (1998), who reported the highest concentrations in summer season to be recorded between $3 \mathrm{pm}$. and $6 \mathrm{pm}$. The biggest difference in the ozone concentration between the absolute maximum and absolute minimum values at daytime was observed between $8 \mathrm{am}$. and $11 \mathrm{am}$. 
a)
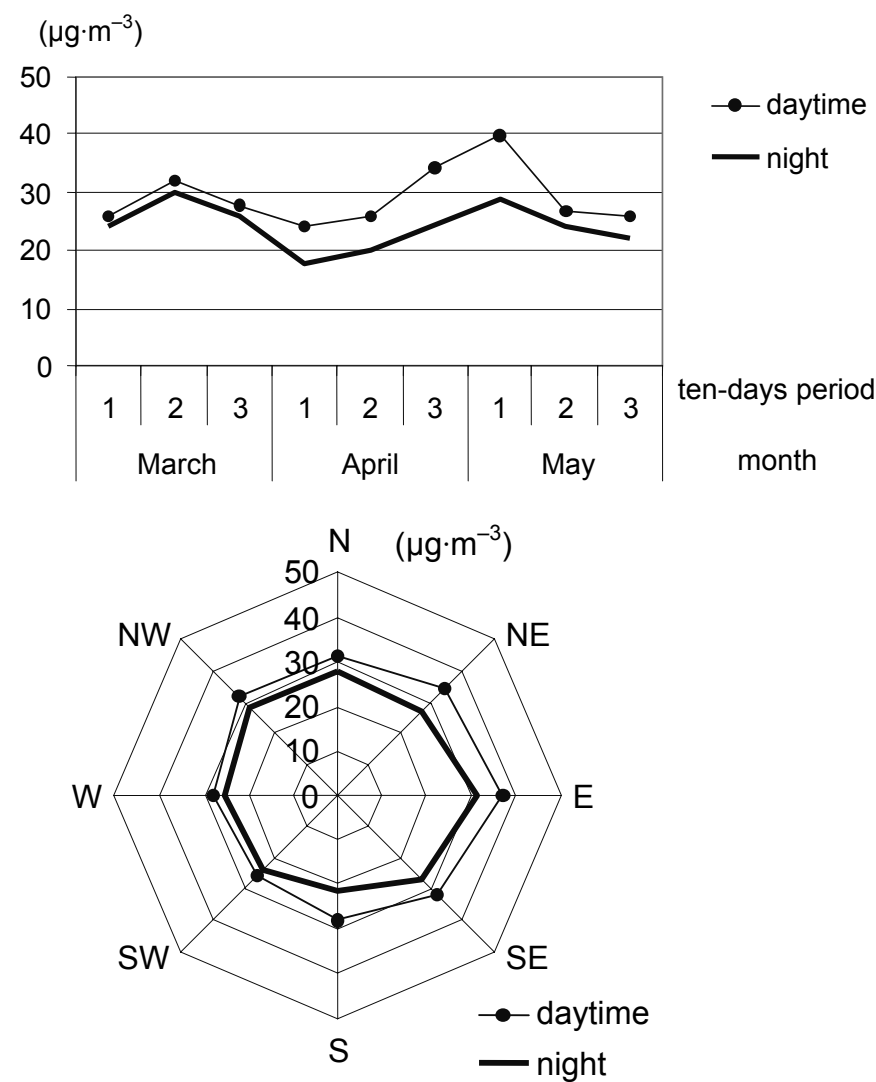

FIGURE 4. Standard deviation for hourly ground-level ozone concentration (a) and wind directions (b)

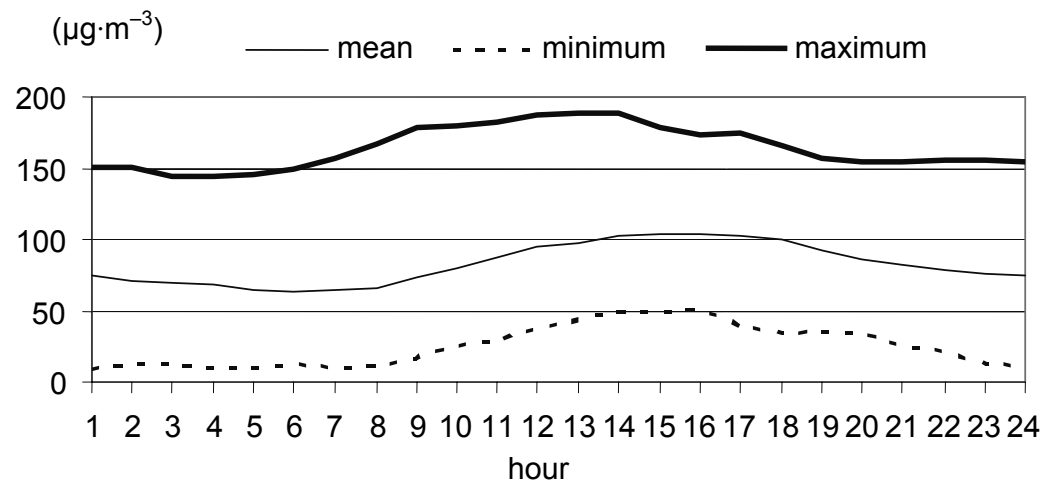

FIGURE 5. Distribution of hourly average and extreme absolute minimal values and absolute maximal ozone concentration in the ground-level air layer over a day 
(typically over $155 \mu \mathrm{g} \cdot \mathrm{m}^{-3}$ ), while the smallest one between $7 \mathrm{pm}$. and $8 \mathrm{pm}$. (typically below $120 \mu \mathrm{g} \cdot \mathrm{m}^{-3}$ ).

Adiagram for hourly frequencies in $\mathrm{O}_{3}$ concentration in the assumed value ranges showed that at Widuchowa station over $59 \%$ of all ozone concentration values recorded at daytime, and more than $65 \%$ recorded at night, fell within the range from 50 to $100 \mu \mathrm{g} \cdot \mathrm{m}^{-3}$. A significantly smaller number of the analysed pollutant concentration values ranged from 100 to $150 \mu \mathrm{g} \cdot \mathrm{m}^{-3}$, namely 28 and $18 \%$ at daytime and at night, respectively, whereas in the first concerned range $<50 \mu \mathrm{g} \cdot \mathrm{m}^{-3}$ it was found 11 and $16 \%$, respectively (Fig. 6). In the 2 first concerned ranges, i.e. $<50$ and 50-100 $\mu \mathrm{g} \cdot \mathrm{m}^{-3}$ concentration values measured at night were found to dominate, whereas the trend was reversed in the ranges 100 -150 and $>150 \mu \mathrm{g} \cdot \mathrm{m}^{-3}$, for which most of the obtained results were calculated from daytime measurements. Values $\geq 100$ $\mu \mathrm{g} \cdot \mathrm{m}^{-3}$ for ozone concentration were most frequently recorded in daily measurements with wind blowing from north $(8.9 \%)$, west $(5.2 \%)$ and south directions $(5.0 \%)$, and at night measurements from the same directions as at the day for the two first wind directions, namely 7.1 and $3.5 \%$, respectively (Fig. 7).

\section{Characteristic meteorological conditions}

As illustrated by 8-direction wind rose for the Widuchowa region in the spring season at daytime the winds predominantly blew from south-western direction and south directions $(24.1 \%$ and $21.9 \%$, respectively), whereas the least frequent were north winds $(2.7 \%)$, while at night east directions $(24.9 \%)$ and north-western directions (2.1\%) were found to be the most and least frequent, respectively (Fig. 8). This has led to the conclusion that the magnitude of tropospheric ozone concentration recorded at Widuchowa is influenced by gaseous pollutants originating not only from the territory of Poland but also from Germany.

Within the concerned season hourly average total solar radiation reached $152.4 \mathrm{~W} \cdot \mathrm{m}^{-2}$ and ranged from 91.2 $\mathrm{W} \cdot \mathrm{m}^{-2}$ in the period from $1 \mathrm{st}$ to 10 th March, to $192.0 \mathrm{~W} \cdot \mathrm{m}^{-2}$ in the period from 21st to 30th April, i.e. in the period when ozone concentration reached the

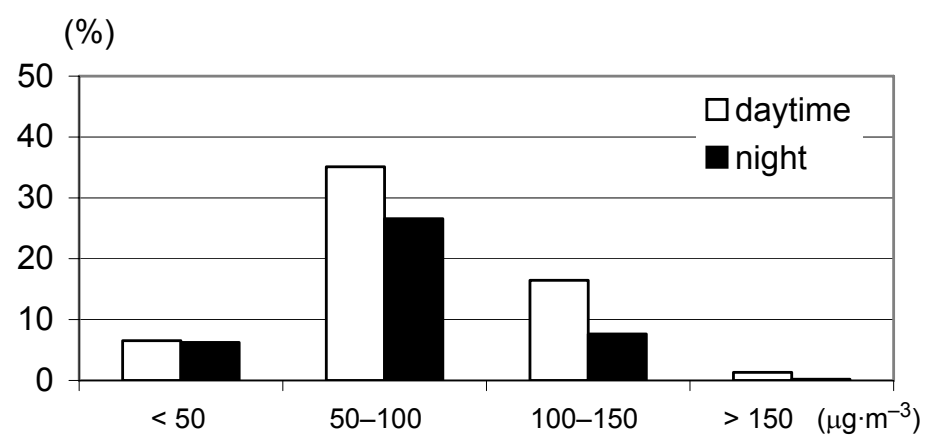

FIGURE 6. Occurrence frequency for hourly ozone concentration values in the ground-level air layer within the assumed ranges 


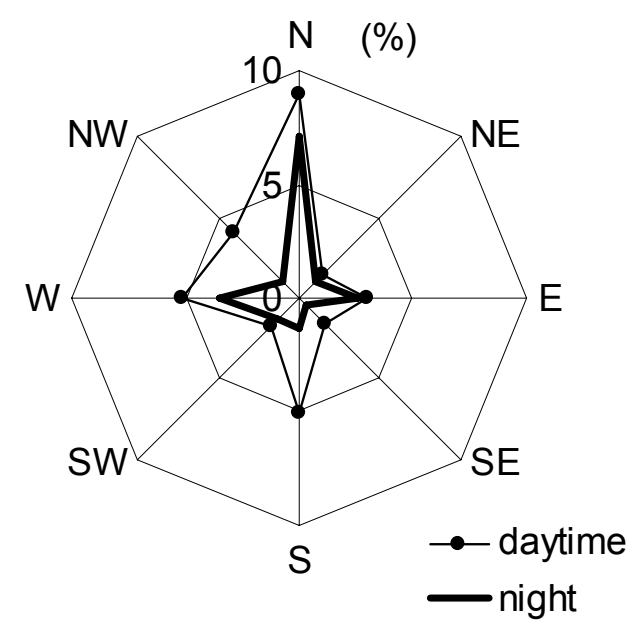

FIGURE 7. Occurrence frequency for hourly ozone concentration values $\geq 100 \mathrm{mg} \cdot \mathrm{m}^{-3}$ in the ground-level air layer as per wind direction

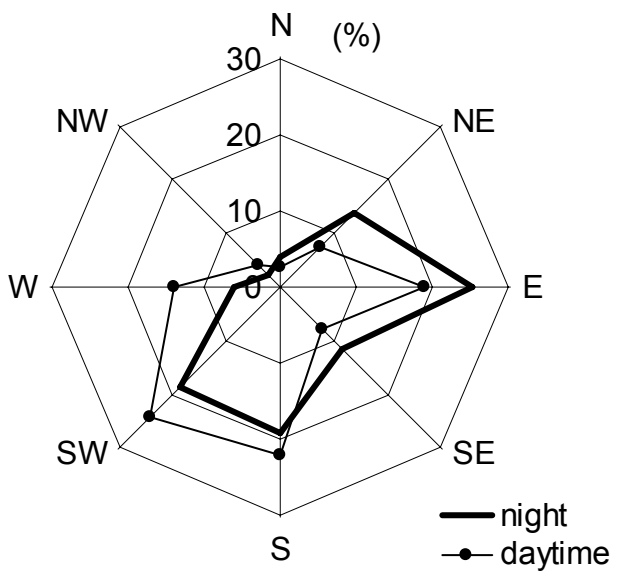

FIGURE 8. Rose of winds

highest value (Fig. 9a). According to Kalbarczyk et al. (2006) in the northwestern Poland the highest insolation occurs in spring, particularly in April and May. The highest value for average solar radiation, in the concerned years 2006 and 2007, coincided with western (185.0 $\left.\mathrm{W} \cdot \mathrm{m}^{-2}\right)$, north-western $\left(166,4 \mathrm{~W} \cdot \mathrm{m}^{-2}\right)$, and eastern circulation $\left(166.0 \mathrm{~W} \cdot \mathrm{m}^{-2}\right)$, while the smallest one coincided with northern circulation $\left(107,6 \mathrm{~W} \cdot \mathrm{m}^{-2}\right)$ (Fig. 9b).

Average spring air temperature reached $8.0^{\circ} \mathrm{C}$, respectively $9.2^{\circ} \mathrm{C}$ and $6.8^{\circ} \mathrm{C}$ at daytime and at night. Temperature in the period from 1st March to the 31st May kept regularly growing from 1.9 to $16.1^{\circ} \mathrm{C}$ at daytime and from 0.6 to $12.4^{\circ} \mathrm{C}$ at night (Fig. 10a). Definitely the highest temperature at daytime $\left(12.1^{\circ} \mathrm{C}\right)$ and at night $\left(9.2^{\circ} \mathrm{C}\right)$ were noted for eastern and north-western winds, respectively (Fig. 10b).

In the spring season the average daily relative air humidity at the region of Widuchowa station reached $69.2 \%$ and varied between $58.2 \%$ in the period from 21 st to 30 th April, to $78.2 \%$ in the period from 1st to 10th March. It is worth noting that typically it was by $11 \%$ lower at daytime than at night, and it oscillated around the level of $64 \%$ (Fig. 11a). At daytime the highest relative humidity was recorded with south-eastern wind $(72.7 \%)$, the lowest $(54.6 \%)$ for wind from eastern direction, i.e. the direction at which the highest average hourly ozone concentration was recorded (Fig. 11b). At night, the scheme develop another pattern - the highest humidity was recorded with south $(80.8 \%)$ and south-western $\quad(79.9 \%)$ circulation, whereas the lowest (69\%), as for the day, at eastern circulation. As Czarnecka et al. (2004) claim the thermal and humid air conditions in this part of Poland are influenced mainly by polar-sea air masses advection, at which the vicinity of Baltic and Lower Odra Valley play the major role. Apart from circulation factors, greatly influential are also physiographic conditions, site topographic profile, its woodness and lakeness. 


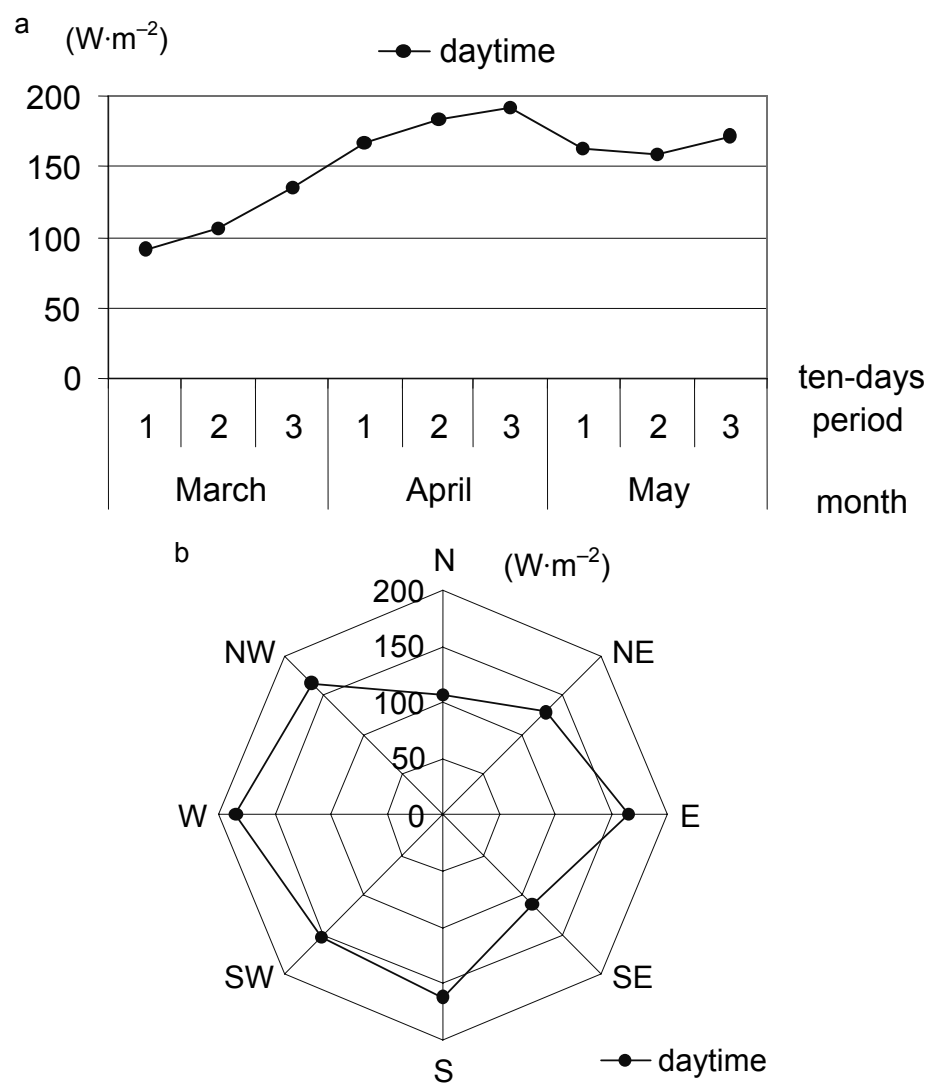

FIGURE 9. Comparison of average hourly solar radiation (a) and wind directions (b)

Among all the meteorological elements under analysis, average hourly atmospheric pressure, proved least variable with regards to day-night difference, and in the period from 1 st March to 10th April slightly lower values for atmospheric pressure were recorded at daytime than at night (by $1.5 \mathrm{hPa}$ ), whereas in the period from 11th April to 31 st May this trend was reversed and pressure was higher at daytime than at night (by $1 \mathrm{hPa}$ ) (Fig. 12a). The lowest average atmospheric pressure, namely $1008.6 \mathrm{hPa}$ at daytime and $1010.9 \mathrm{hPa}$ at night, was recorded in the period from 21st to 31 st March, while the highest values of about $1017 \mathrm{hPa}$ were noted in the period from 11th to 20th March and in the period from 21st to 30th April. With northern, north-eastern and eastern circulations the highest atmospheric pressure of about $1012 \mathrm{hPa}$ was registered, while the lowest one of circa $1004 \mathrm{hPa}$ was observed with the south circulation (Fig. 12b).

Daily average wind speed for the concerned station reached $1.7 \mathrm{~m} \cdot \mathrm{s}^{-1}$, ranging at daytime from $1.4 \mathrm{~m} \cdot \mathrm{s}^{-1}$ in the period from 11th to 20th May to 2.8 $\mathrm{m} \cdot \mathrm{s}^{-1}$ in the period from $21 \mathrm{st}$ to 30 th April, and at night from 1.1 to $2.1 \mathrm{~m} \cdot \mathrm{s}^{-1}$, respectively (Fig. 13a). The highest wind 


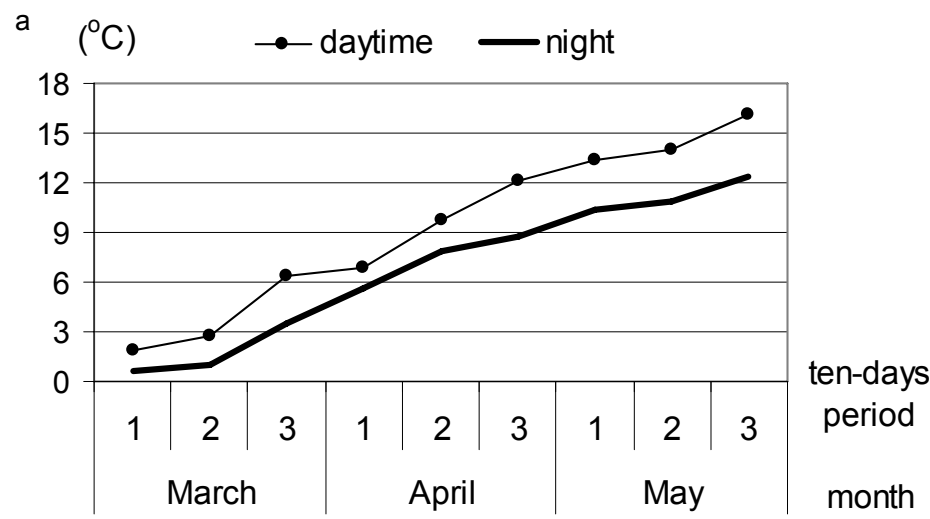

b

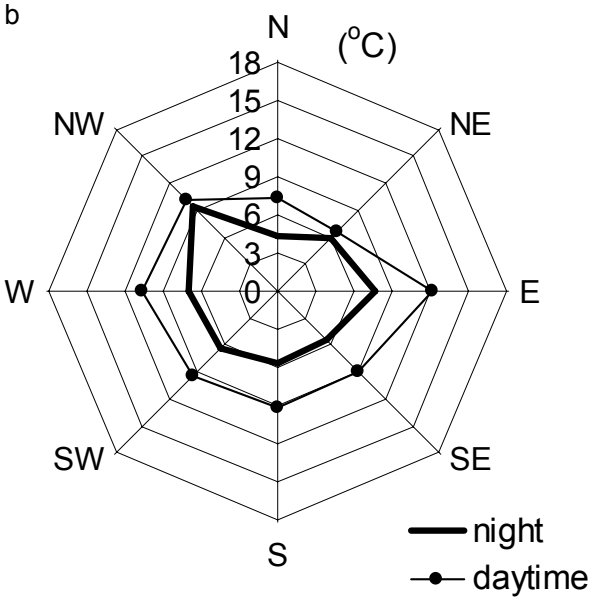

FIGURE 10. Comparison of average hourly temperature (a) and wind directions (b)

speed was noted for winds blowing at daytime from the following directions: $\mathrm{SW}\left(2.6 \mathrm{~m} \cdot \mathrm{s}^{-1}\right), \mathrm{W}\left(2.2 \mathrm{~m} \cdot \mathrm{s}^{-1}\right)$ and $\mathrm{E}(2.1$ $\left.\mathrm{m} \cdot \mathrm{s}^{-1}\right)$ and SW $\left(2.1 \mathrm{~m} \cdot \mathrm{s}^{-1}\right)$ and $\mathrm{W}(2.0$ $\mathrm{m} \cdot \mathrm{s}^{-1}$ ) at night (Fig. 13b).

Figure 14 represents daily pattern for tropospheric ozone concentration set against distributions of the meteorological elements under analysis. To identify the proper relations between the variables, and to keep the picture clear, all the values are shown as \%, to neutralise the particular measurement unites. As shown in the figure, ozone highest concentrations coincided with highest air temperatures, highest wind speed and the lowest relative air humidity, while the highest concentration of the concerned gas was deferred by 4 hours by the maximum of solar radiation that occurred round noon. None dependence between atmospheric pressure and ozone concentration was detected.

\section{Influence of meteorological conditions upon $\mathrm{O}_{3}$ concentration}

Regression analysis of the relation betweentroposphericozoneconcentration and meteorological elements as a 


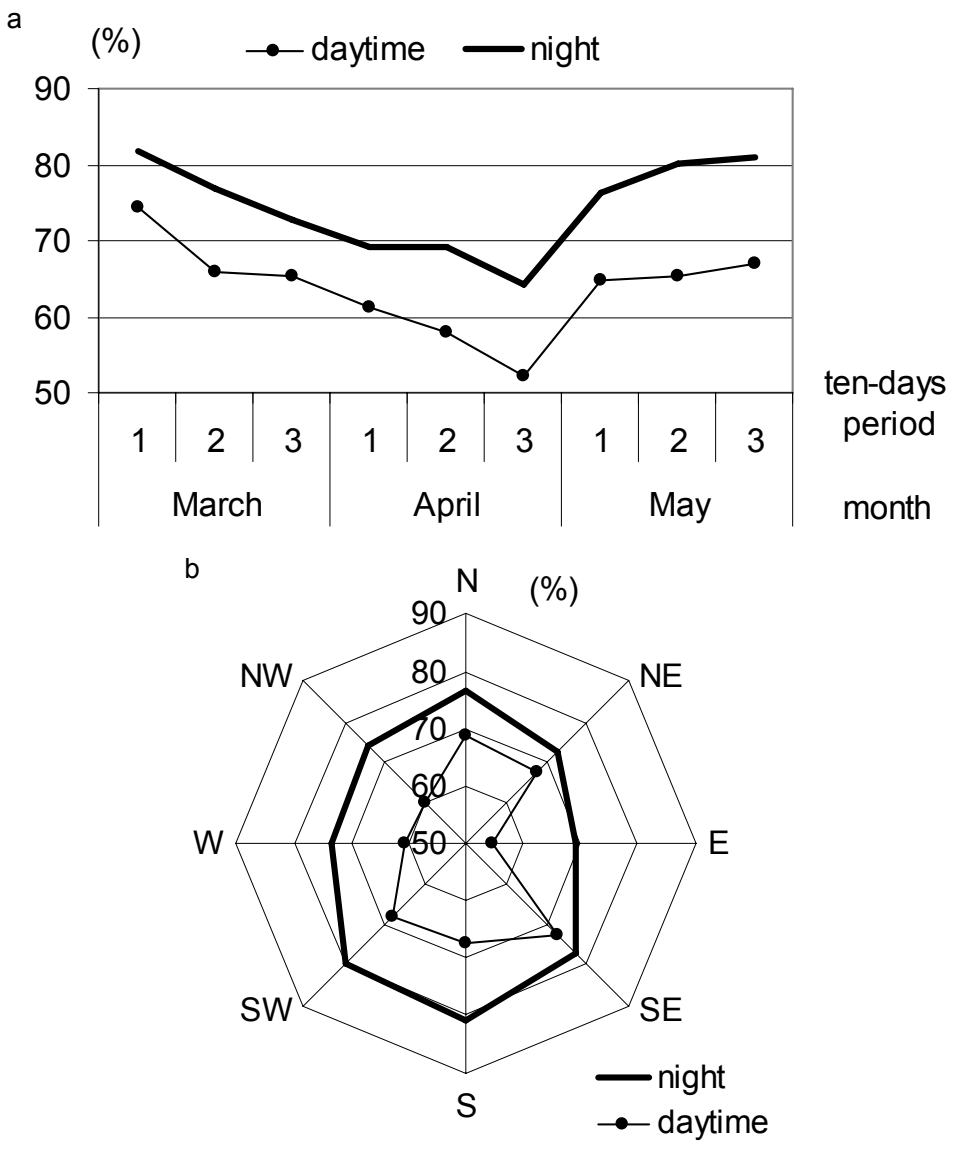

FIGURE 11. Comparison of average hourly relative humidity (a) and wind directions (b)

function of wind direction has proven solar radiation with $\mathrm{N}, \mathrm{E}, \mathrm{S}$ and $\mathrm{SW}$ circulations to have a significant impact on $\mathrm{O}_{3}$ concentration (Tab. 1). Increased solar radiation was found to increase $\mathrm{O}_{3}$ concentration, and the determination coefficient ranged from $2.3 \%$ for SW circulation to $9.4 \%$ with $\mathrm{N}$ circulation; for E circulation, for which the highest level of average concentration, highest absolute value and greatest variability for the concerned gas were found, it reached circa $6 \%$. Solar radiation, and the part of the spectrum of a wave length smaller than $400 \mathrm{~nm}$ to be exact, while interacting evokes photolysis and thus dissociation of nitrogen dioxide, which brings out ozone (Ośródka and Święch-Skiba 1997; Wachowski et al. 2001).

An increase in the average air temperature contributed to higher $\mathrm{O}_{3}$ concentration. Determination coefficients for daytime were clearly higher than for night, and they varied from $2 \%$ with $\mathrm{W}$ direction to $21 \%$ with SE winds, and from $2 \%$ with $\mathrm{S}$ direction to nearly $12 \%$ with SW winds, at daytime and at night, respectively. The strongest dependence was shown at daytime with SE circulation $\left(100 R^{2}=20.5 \%\right)$, 

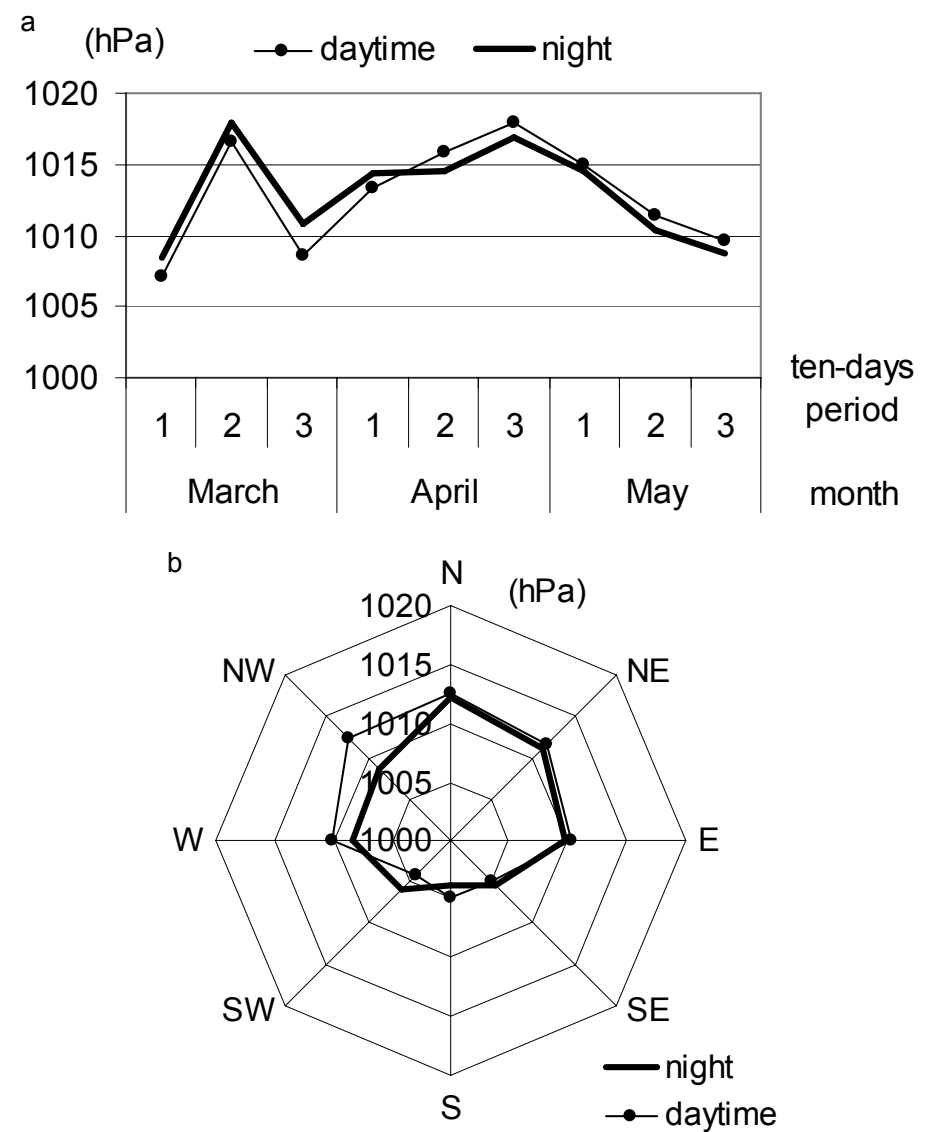

FIGURE 12. Comparison of average hourly atmospheric pressure (a) and wind directions (b)

and with $\mathrm{E}$ circulation $\left(100 R^{2}=17.1 \%\right)$. Strong tropospheric ozone concentration - temperature dependence was also confirmed by Ośródka and Święch-Skiba (1997), Treffeisen and Halder (2000), as well as by Elminir (2005).

Regression analysis of $\mathrm{O}_{3}$ concentration and relative air humidity has shown that this element plays a selectively positive role in the atmosphere purification processes. Determination coefficients for this dependence were high and ranged from 17.7 to $64.8 \%$ at daytime, and from 2.7 to $41.8 \%$ at night; the highest values were recorded for winds blowing from south-eastern and eastern directions. As reported by Elminir (2005) the highest ozone concentration was found for small relative humidity, i.e. $\leq 40 \%$. Ośródka and Święch-Skiba (1997) claim that increased relative humidity can result in eliminating ozone from the atmosphere via ozone reactions with water.

At selected circulation directions, namely E, SW and NW significant, positive impact of atmospheric pressure on $\mathrm{O}_{3}$ imission value was found, though at daytime only. Similar results have been reported by Godłowska (2004), where increased ozone concentration 


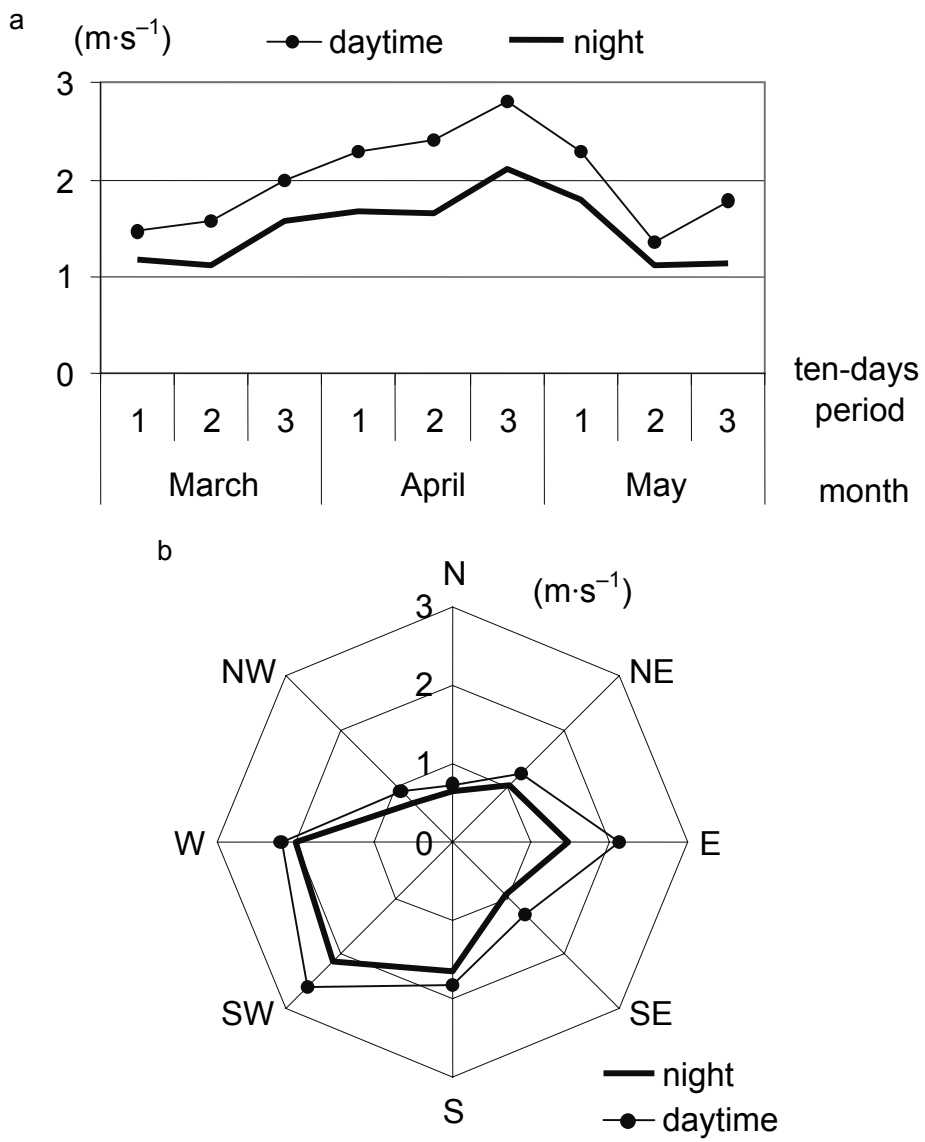

FIGURE 13. Comparison of average hourly wind speed (a) and wind directions (b)

level contributed to an increase in the in the region of Widuchowa station. atmospheric pressure over the warm half Increased average $\mathrm{O}_{3}$ concentration of the year. Under anti-cyclone synoptic with higher wind speed can be attributed conditions and stable air masses balance, to the fact that recorded imission is a photochemical smog frequently likely to be greatly impacted by other occurs, usually accompanied by high pollutant sources located in a specific temperature, low relative humidity, sunny distance from the measurement station weather and clear sky at daytime. Strong (Treffeisen and Halder 2000; Walczewski relations between ozone concentration 2000). It is additionally supported by and anti-cyclone weather were proved analysis performed by Dueńas'a et al. by Davis et al. (1998), as well by as (2002) and Godłowska (2004), where for Godłowska and Tomaszewska (2006).

Regression analysis between $\mathrm{O}_{3}$ concentration and wind speed has shown selectively negative role of this elements warmer half-year increased wind speed determines higher $\mathrm{O}_{3}$ concentrations. The highest ozone concentrations are observed in the suburban areas and in 


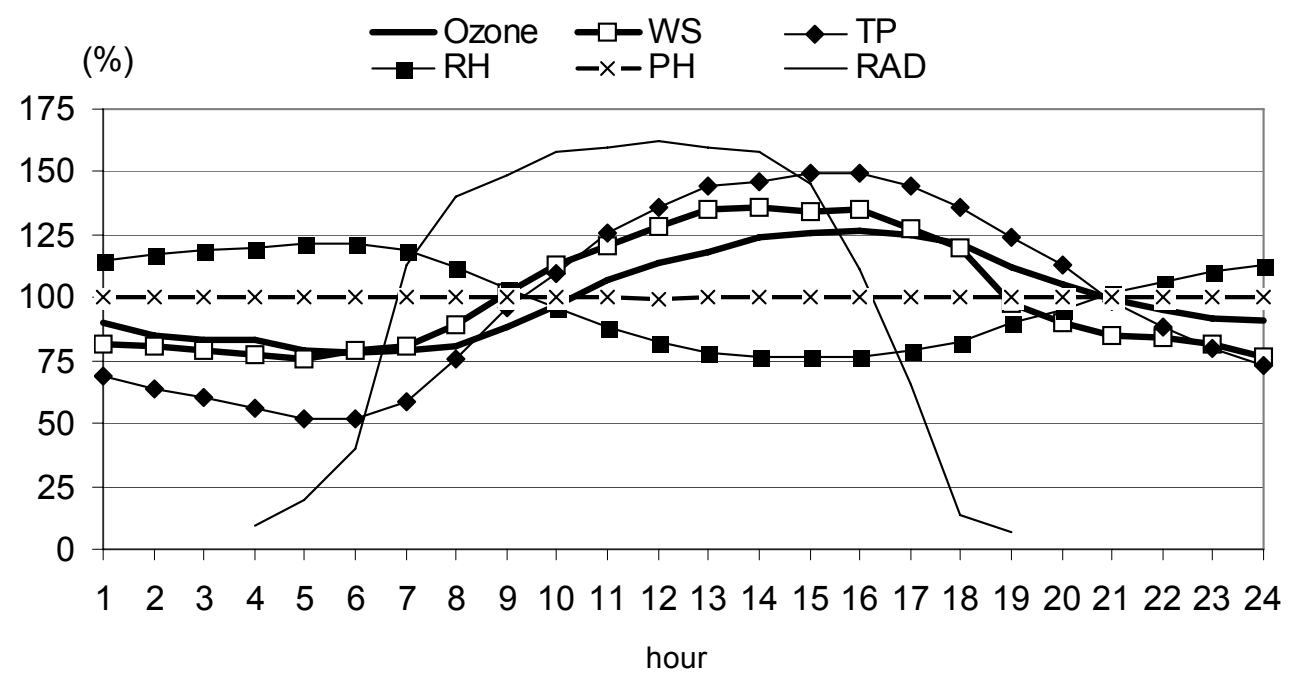

$\mathrm{RAD}$ - mean total solar radiation, $\mathrm{TP}$ - mean air temperature, $\mathrm{RH}$ - mean air humidity, $\mathrm{PH}$ - mean air-pressure, WS - mean wind speed.

FIGURE 14. Distribution over daytime for hourly ozone concentration in the ground-level air layer set against meteorological elements dependencies (all values as \%)

even further distanced rural areas where no local nitrogen emission sources located by lee side of the major ozone precursors emission sources can be found. When the air is transported by wind, $\mathrm{NO}_{2}$ undergoes photolysis which finally results in ozone (Godłowska 2004; Godłowska and Tomaszewska 2006). Determination coefficients for such dependence ranged from 4.1 to $31.2 \%$ at daytime, and from 3.5 to $27.9 \%$ at night, with the highest values obtained with $\mathrm{N}$ and $\mathrm{E}$ circulation, respectively.

The final stage of the presented research was to identify a weather cluster, though only for daytime and eastern circulation, i.e. for the highest noted average troposphere ozone concentration in the spring season at Widuchowa station. By analysing the clusters, three observation groups of meteorological elements were selected with different weather cluster characteristics for daytime with eastern winds, which favored various ozone concentrations in the region of Widuchowa station (north-western Poland). From all the selected clusters, only for cluster 1 the highest values of total solar radiation, average temperature, atmospheric pressure, wind speed and lowest relative humidity coincided. Cluster 2 was in a way a reverse of cluster 1 , apart from the value for atmospheric pressure, while cluster 3 displayed average values for all the concerned meteorological elements, excluding atmospheric pressure (Fig. 15).

As induced by variance analysis, it can seen that all the statistically significant at the level $\mathrm{P} \leq 0.01$ meteorological elements (solar radiation, air temperature, relativeairhumidity, atmospheric pressure and wind speed) make the selected cluster different, hence significantly determine various ozone concentrations analysed at daytime with eastern circulation 


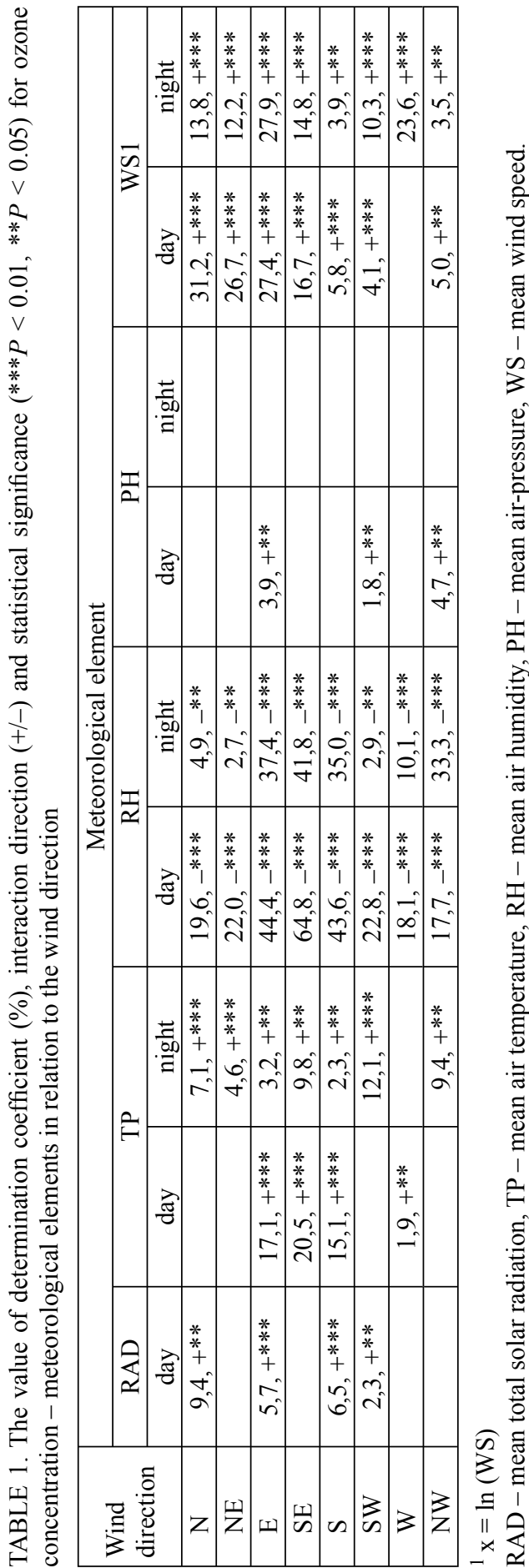

(Tab. 2), which is in line with the results obtained by regression analysis (Tab. 1). The highest values for Fisher's test were obtained for atmospheric pressure, and relative humidity, whereas the lowest ones for solar radiation. Single regression analysis, on the contrary to the variance analysis, proved the relative air humidity $\left(100 R^{2}=44.4 \%\right)$ and wind speed $\left(100 R^{2}\right.$ $=27.4 \%$ ), impacts to be the strongest, while atmospheric pressure $\left(100 R^{2}=\right.$ $=3.9 \%$ ) impacts the weakest. Observed differences in the ranking for particular meteorological elements as long as ozone concentration is explained could be most likely attributed to the fact that the whole package of weather conditions is tested in clustering analysis, while single regression analysis concerns each element separately.

As Table 3 illustrated it, Cluster 1 consisted of 210 , cluster 2 of 126 , and cluster 3 of 130 observations. To assess the impact of the whole set of meteorological elements on the ozone concentration in all observations grouped within particular clusters, average ozone concentrations and average values for particular meteorological elements were calculated separately. Additionally, to $\mathrm{O}_{3}$ concentration values standard deviations were shown, and for the meteorological elements their extreme values, namely their minimal and maximal values plus standard deviations were reported. The highest average ozone concentration equal to $122.6 \mu \mathrm{g} \cdot \mathrm{m}^{-3}$ at daytime with eastern circulation were found for cluster 1 , whereas the smallest of $66.5 \mu \mathrm{g} \cdot \mathrm{m}^{-3}$ for cluster 2. Cluster 1 (high concentration) displayed a bit higher standard deviation for ozone concentration than clusters 2 (low concentration) and 3 (average 


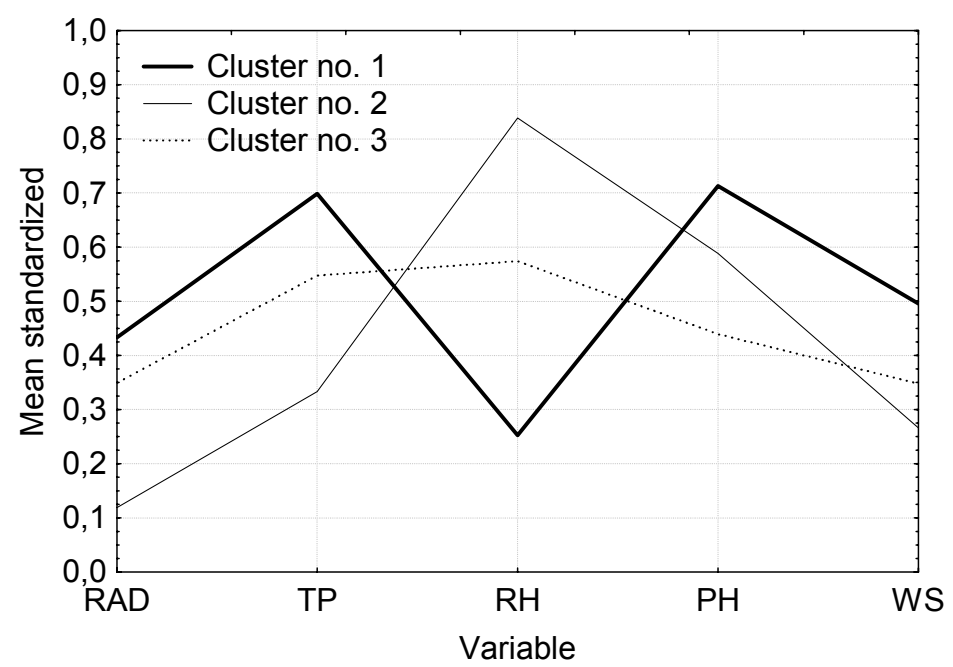

FIGURE 15. Standardized average values for meteorological elements for various $\mathrm{O}_{3}$ concentration at daytime with south wind for each separated cluster. For explanations, see Table 1.

TABLE 2. Statistical assessment with variance analysis of the selected clusters as based on meteorological elements for various $\mathrm{O}_{3}$ concentrations at daytime with south wind direction

\begin{tabular}{|l|r|r|r|r|r|c|}
\hline Variable & \multicolumn{1}{|c|}{$\mathrm{SS}$} & \multicolumn{1}{|c|}{$\mathrm{Df}_{\mathrm{SS}}$} & \multicolumn{1}{c|}{$\mathrm{SSE}$} & $\mathrm{Df}_{\text {SSE }}$ & $\mathrm{F}$ & $\mathrm{P}$ \\
\hline $\mathrm{RAD}$ & 13289511.4 & 2 & 5187577.7 & 463 & 593.1 & 0.00 \\
\hline $\mathrm{TP}$ & 80646.2 & 2 & 14408.0 & 463 & 1295.8 & 0.00 \\
\hline $\mathrm{RH}$ & 1570944.3 & 2 & 58255.2 & 463 & 6242.8 & 0.00 \\
\hline $\mathrm{PH}$ & 475648568.8 & 2 & 18871.9 & 463 & 5834746.9 & 0.00 \\
\hline WS & 2222.7 & 2 & 400.6 & 463 & 1284.5 & 0.00 \\
\hline
\end{tabular}

$\mathrm{SS}$ - sum square error of between-group variation,

$\mathrm{Df}_{\mathrm{SS}}-$ number of degrees of freedom for sum square error SS,

SSE - sum square error of within-group variation,

$\mathrm{Df}_{\mathrm{SSE}}$ - number of degrees of freedom for sum square error SSE,

F - Fisher's test,

$\mathrm{P}-$ level of probability.

Other explanation, see Table 1.

concentration); it reached $29.2 \mu \mathrm{g} \cdot \mathrm{m}^{-3}$. Average ozone concentration observed at daytime, with eastern wind (clusters $1-3$ ), was found to be at the level similar to cluster 3 (average concentration); for which the value of $98.8 \mu \mathrm{g} \cdot \mathrm{m}^{-3}$ was reported. High ozone concentrations, on average of the value of $122.6 \mu \mathrm{g} \cdot \mathrm{m}^{-3}$ (cluster 1) seem to be favored by the following weather cluster: higher than average total solar radiation, reaching circa $209 \mathrm{~W} \cdot \mathrm{m}^{-2}$, higher than average value, mean temperature of $17.0^{\circ} \mathrm{C}$, relative humidity below the average value, reaching circa $35 \%$, atmospheric pressure of $1016 \mathrm{hPa}$ over the average value, and last but not least higher than average, i.e. equal to $2.7 \mathrm{~m} \cdot \mathrm{s}^{-1}$, average wind 


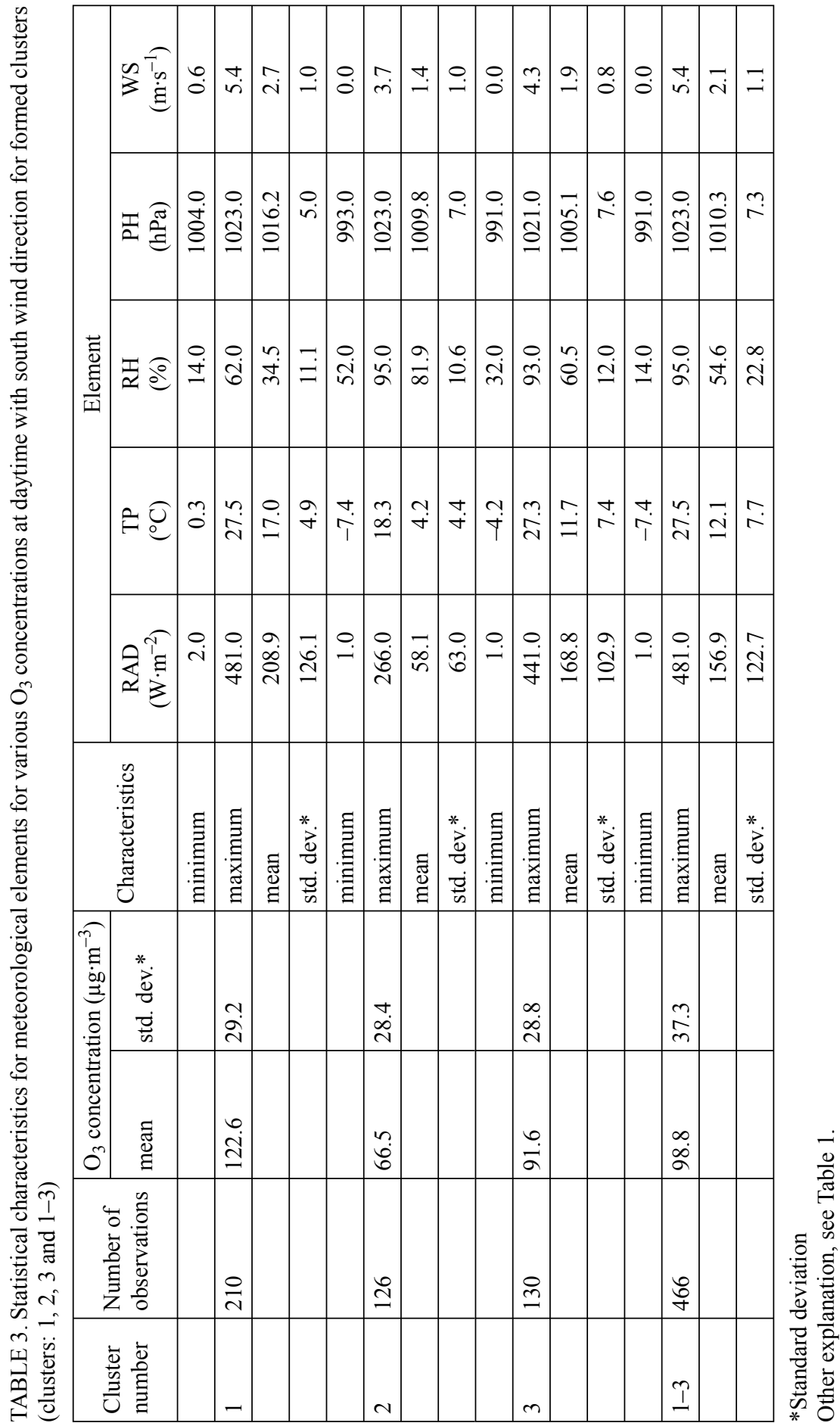


speed. As shown in Table 3 the highest standard deviations tend to be placed within cluster 3 (temperature, humidity, pressure), while the lowest ones in cluster 2 (radiation, temperature, humidity). Absolute maximal and absolute minimal values for meteorological elements tend to group in cluster 1 , with the exception of relative humidity for which a minimal value was found in cluster 1 .

\section{RECAPITULATION}

In the region of Widuchowa station located in north-western Poland time distribution for ozone concentration in the ground-level air layer displayed a distinct seasonal and daily structure. In the spring season (March-May) $\mathrm{O}_{3}$ imission value was nearly twice higher than in the winter season and it reached $82.5 \mu \mathrm{g} \cdot \mathrm{m}^{-3}$. In the spring higher ozone concentration, on average by $9.3 \mu \mathrm{g} \cdot \mathrm{m}^{-3}$, were observed at daytime than at night, with the maximum of $98.8 \mu \mathrm{g} \cdot \mathrm{m}^{-3}$ for eastern circulation, and the minimum of $72.3 \mu \mathrm{g} \cdot \mathrm{m}^{-3}$ for south-eastern circulation. At daytime the highest, even higher than $100 \mu \mathrm{g} \cdot \mathrm{m}^{-3}$, values for concentrations of the concerned gas were noted between $2 \mathrm{pm}$. and $6 \mathrm{pm}$., while the lowest ones, not higher than $66 \mu \mathrm{g} \cdot \mathrm{m}^{-3}$, between 5 am. and $8 \mathrm{am}$. Over $59 \%$ of all the ozone concentration measurements recorded at daytime and over $65 \%$ at night, fell within the range $50-100 \mu \mathrm{g} \cdot \mathrm{m}^{-3}$. High ozone concentration of values $\geq 100$ $\mu \mathrm{g} \cdot \mathrm{m}^{-3}$ recorded at daytime were most frequently observed with the wind blowing from the northern $(8.9 \%)$ or western $(5,2 \%)$ direction; a similar effect was found at night, though the frequency tended to lower to 7.1 and $3.5 \%$. The highest number of significant relations between $\mathrm{O}_{3}$ concentration and meteorological elements were found for relative air humidity and average wind speed. Among all the concerned meteorological elements a definite adverse effect upon the clear atmosphere were proven for increased total solar radiation, air temperatures, atmospheric pressure and wind speed, as well as decreased relative air humidity; the effect was observed regardless the circulation pattern. The highest average tropospherie ozone concentration noted at daytime and with eastern circulation was favored by the following weather cluster: values higher than average: average total solar radiation of about $209 \mathrm{~W} \cdot \mathrm{m}^{-2}$, average air temperature equal to $17.0^{\circ} \mathrm{C}$, pressure atmosphere of about $1016 \mathrm{hPa}$, average wind speed of $2.7 \mathrm{~m} \cdot \mathrm{s}^{-1}$, and lower than average relative air humidity of about $35 \%$.

\section{REFERENCES}

BAUR D., SAISANA M., SCHULZE N. 2004: Modeling the effects of meteorological variables on ozone concentration - a quantile regression approach. Atmospheric Environment 38, 4689-4699.

BOGUCKAM.2006:Wstępnewynikianalizy zmienności ozonu niskotroposferycznego w Polsce na stacjach tła zanieczyszczenia atmosfery [Preliminary results of analysis of ground-level ozone variability in Poland on the background air pollution monitoring stations IMGW in 1996-2003]. Wiad. IMGW 29 (50), 17-29 [Engl. summ.].

BRACE S., PERTERSON D.L. 1998: Spatial patterns of tropospheric ozone 
in the Mount Rainier Region of the cascade mountains, U.S.A. Atmospheric Environment 32, 3629-3637.

BYTNEROWICZ A., BADEA O., BARBU I., FLEISCHER P., FRĄCZEK W., RANCZ V., GODZIK B., GRODZIŃSKA K., GRODZKI W., KARNOSKY D., KOREN M., KRYWULT M., KRZAN Z., LONGAUER R., MAŇKOVSKÁ B., MANNING W. J., MC MANUS M., MUSSELAMN R., NOWOTNY J., POPESCU F., POSTELNICU D., PRUS-GŁOWACKI W., SKAWIŃSKI P., SKIBA S., SZARO R., TAMAS S., VASILE C. 2003: New international longterm ecological research on air pollution effects on the Carpathian Mountain forests. Central Europe. Environment International 29, 367-376.

CZARNECKA M., KOŹMIŃSKI C., MICHALSKA B., KALBARCZYK E., KALBARCZYK R. 2004: Warunki wilgotnościowe powietrza i gleby na Pomorzu [Air humidity and soil moistness conditions in Pomerania]. In: Rojek M. (Red.). Współczesne problemy inżynierii środowiska. III. Bilanse wodne ekosystemów rolniczych [Contemporary problems of environmental engineering. III. Water balances of agricultural ecosystems]. Wyd. AR Wrocław, 27-45 [Engl. summ.].

COOPER S.M., PETERSON D.L. 2000: Spatial distribution of tropospheric ozone in western Washington, USA. Environmental Pollution 107, 339-347.

DAVIS J.M., EDER B.K., NYCHKA D., YANG Q. 1998: Modeling the effects of meteorology on ozone in Houston using cluster analysis and generalized additive models. Atmospheric Environment 32, 14/15, 2505-2520.

DOBOSZ M. 2001: Wspomagana komputerowo statystyczna analiza wyników badań [Computerized statistical analysis of results]. Akademicka Oficyna Wyd. EXIT. Warszawa [In Polish].

DUEÑAS C., FERNÁNDEZ M.C, CAÑETE S., CARRETERO J., LIGER E. 2002:
Assessment of ozone variations and meteorological effects in an urban area in the Mediterranean Coast. The Science of the Total Environment 299, 97-113.

ELMINIR H.K. 2005: Dependence of urban air pollutants on meteorology. Science of the Total Environment 350, 225-237.

FELZER B.S., CRONIN T., REILLY J.M., MELILLO J.M., WANG X. 2007: Impacts of ozone on trees and crops. C.R. Geoscience 339, 784-798.

GODŁOWSKA J. 2004: Analiza zmienności średnich 8-godzinnych ozonu (10-18 GMT) na terenie Polski i ich związki z meteorologia [Analysis of variability of mean 8-hour ozone concentration (10 to 18 UTC) over Poland and its connection to meteorology]. Wiad. IMGW 26(47), 67-78 [Engl. summ.].

GODŁOWSKA J., TOMASZEWSKA A.M. 2006: Zależność średnich 8-godzinnych stężeń ozonu $\left(8 \mathrm{O}_{3}\right)$ od typów cyrkulacji J. Lityńskiego na stacjach krajowego monitoringu ozonu [8-hour mean ozone concentration $\left(8 \mathrm{O}_{3}\right)$ vs. Litynski's types of circulation at stations of national ozone monitoring]. Wiad. IMGW 29 (50), 3-16 [Engl. summ.].

HARTIGAN J.A. 1975: Clustering algorithms. New York: J. Wiley and Sons.

HOLDEN N.M., BRERETON A.J. 2004: Definition of agroclimatic regions in Ireland using hydro-thermal and crop yield data. Agric. Forest Meteorol. 122, 175-191.

KALBARCZYK R., KALBARCZYK E., BŁASZKOWSKA M. 2006: Struktura czasowa usłonecznienia rzeczywistego na Nizinie Szczecińskiej w latach 20002004 [Time structure of real sunshine in the Szczecin Lowlands in 2000-2004]. Przegl. Nauk. IKŚ 33, 114-122 [Engl. summ.].

LANDSBERG-UCZCIWEK M., REWAJ R., TRYBUCHOWICZ A. [red.] 2007: Pięcioletnia ocena jakości powietrza za lata 2002-2006 pod kątem $\mathrm{SO}_{2}, \mathrm{NO}_{2}$, $\mathrm{NO}_{\mathrm{x}}, \mathrm{PM} 10, \mathrm{~Pb}, \mathrm{CO}, \mathrm{C}_{6} \mathrm{H}_{6}$ and $\mathrm{O}_{3}$ dla stref 
województwa zachodniopomorskiego [A five-year assessment of air quality for the years 2002-2006 in terms of $\mathrm{SO}_{2}$, $\mathrm{NO}_{2}, \mathrm{NO}_{\mathrm{x}}, \mathrm{PM} 10, \mathrm{~Pb}, \mathrm{CO}, \mathrm{C}_{6} \mathrm{H}_{6}$ and $\mathrm{O}_{3}$ for Zachodniopomorskie voivodship zones]. IOŚ-WIOS Szczecin [In Polish].

LEHMAN J., SWINGTON K., BORTNIK S., HAMILTON C., BALDRIDGE E., EDER B., COX B. 2004: Spatio-temporal characterization of tropospheric ozone across the estern Unite States. Atmospheric Environment 38, 4357$-4369$.

MANNING W.J., GODZIK B., MUSSELMAN R. 2002: Potential bioindicator plant species for ambient ozone in forested mountain areas of central Europe. Environmental Pollution 119, 283-290.

MAŇKOVSKA B., PERCY K., KARNOSKY D.F. 1999: Impact of ambient tropospheric $\mathrm{O}_{3}, \mathrm{CO}_{2}$ and particulates on the epicuticular waxes of aspen clones differing in $\mathrm{O}_{3}$ tolerance. Ekológia (Bratislava) 18 (2), 200-210.

MAŇKOVSKÁB.,ČERNYM.,MORAVČIK P., GODZIK B., GRODZIŃSKA K., BADEA O., BARANČOK P., OSZLÁNYI J., VARŠAVOVÁ M., FLEISCHER P., BLUM O., PARPAN V., BYTNEROWICZ A., SZARO R. 2002: Chemical and Morphological Changes in Carpathian Mountains Trees Caused by Air Pollution. In: Szaro R., Bytnerowicz A., Oszlányi J. [Eds.]. Effects of air pollution on forest health and biodiversity in forests of the carpathian mountains. NATO Science Series. Series I: Life and Behavioural Sciences. IOS Press. Amsterdam. Vol. 345, 173-184.

MAZZEO N.A., VENEGAS L.E., CHOREN H. 2005: Analysis of $\mathrm{NO}, \mathrm{NO}_{2}, \mathrm{O}_{3}$ and $\mathrm{NO}_{\mathrm{x}}$ concentrations measured at green area of Buenos Aires City during wintertime. Atmospheric Environment 39, 3055-3068.

OŚRÓDKA L., ŚWIĘCH-SKIBA J. 1997: Klimatlogiczne aspekty powstawania smogu letniego na obszarze Górnośląskieo
Okręgu Przemysłowego [Climatological aspects of the origin of a summer smog over the area of Upper-Silesia Industry Region]. Wiad. IMGW 20 (41), 113-128 [Engl. summ.].

SOBCZYK W. [red.] 1998: Statystyka, podstawy teoretyczne, przykłady zadania [Statistics. Theoretical grounds, examples - problems]. Wyd. UMCS Lublin [In Polish].

TREFFEISEN R., HALDER M. 2000: Spatial and temporal variations of ozone concentrations at high altitude monitoring sites in Germany. Environmental Monitoring and Assessment 65, 139-146.

WACHOWSKI L., KIRSZENSZTEJN P., FOLTYNOWICZ Z. 2001: Ecological replacementsofozone-depletingubstances. Polish Journal of Environmental Studies 10 (6), 415-435.

WALCZEWSKI J. [red.] 2000: Wykorzystanie danych meteorologicznych w monitoringu jakości powietrza (podstawy fizyczne i wskazówki metodyczne) [Utilization of meteorological data in air quality monitoring (physical bases and methodological guidelines)]. Biblioteka Monitoringu Środowiska. Warszawa [In Polish].

WALCZEWSKI J. 2005: Meteorologiczne i klimatyczne uwarunkowania rozprzestrzeniania się zanieczyszczeń powietrza [The meteorological and climatological conditions of the air pollution dispersion in the atmosphere]. Przegl. Geofizyczny 50 (3-4), 177-194 [Engl. summ.].

Streszczenie: Stężenie ozonu w przyziemnej warstwie powietrza $w$ pótnocno-zachodniej Polsce - rola elementów meteorologicznych. Celem pracy było poznanie struktury czasowej oraz zmienności ozonu troposferycznego $\mathrm{w}$ powiązaniu z przebiegiem warunków meteorologicznych dnia i nocy, zwłaszcza w sezonie wiosennym (marzec-maj) oraz wydzielenie kompleksu pogodowego, któremu towarzyszyło najwyższe stężenie $\mathrm{O}_{3}$. Podstawę opracowania stanowiły wartości godzinne stężenia $\mathrm{O}_{3}$ oraz godzinne dane pięciu elementów meteorologicznych (całkowite pro- 
mieniowanie słoneczne, temperatura powietrza, wilgotność względna powietrza, ciśnienie atmosferyczne oraz kierunek i prędkość wiatru) w okresie od 01.11.2005 r. do 31.10.2007 r., pochodzące ze stacji Widuchowa zlokalizowanej przy granicy polsko-niemieckiej w północno-zachodniej Polsce. Najwyższe średnie stężenie ozonu notowano w dzień przy wietrze wiejącym z kierunku wschodniego, w warunkach niskiej wilgotności względnej powietrza (około 35\%) oraz wysokich wartości całkowitego promieniowania słonecznego (około $209 \mathrm{~W} \cdot \mathrm{m}^{-2}$ ), temperatury powietrza $\left(17,00^{\circ} \mathrm{C}\right.$ ), ciśnienia atmosferycznego (około 1016 $\mathrm{hPa})$, prędkości wiatru $\left(2,7 \mathrm{~m} \cdot \mathrm{s}^{-1}\right)$. Stwierdzono, że o wielkości stężenia ozonu troposferycznego rejestrowanego w stacji Widuchowa decyduja zanieczyszczenia gazowe pochodzące nie tylko z terytorium Polski, ale również z Niemiec.

MS received - January 2009
Authors' address:
Akademia Rolnicza w Szczecinie Katedra Meteorologii i Klimatologii ul. Papieża Pawła VI nr 3, 71-469 Szczecin Poland
e-mail: robkalb@agro.ar.szczecin.pl 